\title{
EXPEDIENCY OF USING THE STAKEHOLDER'S APPROACH FOR ACHIEVING THE SYSTEM STABILITY OF THE PROCESS OF FOOD SECURITY
}

\author{
ДОЦІЛЬНІСТЬ ЗАСТОСУВАННЯ \\ СТЕЙКХОЛДЕРСЬКОГО ПІДХОДУ ДЛЯ ДОСЯГНЕННЯ \\ СТАНУ СИСТЕМНОЇ СТАБІЛЬНОСТІ ПРОЦЕСУ \\ ПРОДОВОЛЬЧОГО ЗАБЕЗПЕЧЕННЯ
}

\section{Hlubish Lesia ${ }^{1}$}

DOI: http://dx.doi.org/10.30525/978-9934-571-28-2_8

\begin{abstract}
There is a need for eliminating disparities, characteristic for the modern model of functioning of the sphere of food supply, which must guarantee food security in order to preserve food independence, which is a prerequisite for sustainable economic development of the country. It is necessary to use an integrated approach, which would allow to identify ways to optimize the effectiveness of market interaction for all stakeholders as a system-forming component of the sphere of food provision.

Often, the concepts of "food provision" and "food security" are identified, in fact the second category is the result of and the first - the process, aimed at achieving this result. Therefore, the purpose of this scientific study is to clearly delineate the definitions "food provision" and "food security" and proving of their cause-effect relationship, also definition of the concept of the category "sphere of food provision". And on this theoretical basis prove the feasibility of stakeholder approach, the tools of which will help to identify the causes of imbalance of tripartite market interaction and outline the necessary steps to balance economic interests of stakeholders of the sphere of food provision to optimize the economic effect of their market interactions.

According to the results of the study, it was established, that food provision is an action aimed at achieving the result - food security. The essence of the concept of the sphere of food supply is also disclosed from the standpoint of the stakeholders' interaction environment. The expediency of using

\footnotetext{
${ }^{1}$ Candidate of Economic Sciences, Associate Professor, Associate Professor of Technology Management Department, Lviv Polytechnic National University, Ukraine
} 
the stakeholder approach is substantiated a convenient and effective tool to ensure food security, which allows to determine the mission, strategic goal and tactical goal of the functioning of the food provision sphere, as well as its subjective-functional components. The emphasis is placed on the fact, that when formulating the purpose and objectives of economic activity, each subject of market relations should be guided by the general mission of functioning of the sphere of food provision.

It is revealed that the paradigm of values serves as the dominant factor in determine of the targets stakeholders which are regulators of their behavior in the market interaction. Values and goals in aggregate influence the formation of interests of interested parties. In order to harmonize economic relations and problem solving confrontation and different orientations of aspirations about obtaining economic benefit between the sides of market interaction, it is necessary to balance the interests of stakeholders, based on the results of the force field analyses achieving of the system stability of the food provision process, that allows you to define a clear threat and to build an appropriate system of priorities for strategic development of food provision in a concrete perspective.

It was established, that the main effect of interaction of sphere of food provision stakeholders is to achieving the status of systemic stability process of the food provision of the population of our country in order to preserve the health of the nation.

\section{1. Ветуп}

Розвиток людської цивілізації на пряму залежить від продуктивної діяльності людини, тому продовольчому фактору завжди відводилась важлива роль. Динамічність сучасного життя характеризується недостатніми обсягами середньодушового споживання продуктів харчування та невідповідністю енергетичного вмісту добових раціонів, що призвело до зростання смертності, загальної захворюваності та скорочення тривалості життя населення. Поряд зі зниженням технологічних якостей спостерігається погіршення харчової цінності продовольства, в результаті споживання якого організм людини недоотримує необхідних макро- та мікроелементів, що призводить до формування, так званого, «прихованого голоду». Тобто навіть за умови кількісно достатнього споживання продуктів харчування із допустимою енергетичною цінністю споживач недоотримує з їжею низку життєво необ- 


\section{Hlubish Lesia}

хідних речовин. Попри скорочення чисельності населення таке явище $\epsilon$ основною причиною зростаючих потреб у продовольстві. У свою чергу, зростаючі обсяги споживання спонукають до збільшення обсягів виробництва, проте таких же бідних на вітаміни продуктів, реалізація яких приносить виробнику неабияку економічну вигоду. Таке явище спровоковане низьким рівнем купівельної спроможності, через що поряд із дієтичною неповноцінністю існує проблема фізичної та економічної доступності продуктів харчування. Усе це свідчить про розбалансованість ринкової взаємодії виробника і споживача, зумовленої невтручанням держави та вимагає виявлення й дослідження чинників, що провокують загальне відчуття продовольчого неблагополуччя для левової частки населення України.

В умовах окреслених загроз продовольчій безпеці постає проблема збереження здорового генофонду нації. Обов'язковою умовою ï вирішення $є$ усунення диспропорцій, характерних для сучасної моделі функціонування сфери продовольчого забезпечення, покликаної гарантувати продовольчу безпеку задля збереження продовольчої незалежності - обов'язкової умови стійкого економічного розвитку країни. Виникає потреба у впровадженні комплексного підходу, який би гарантував оптимальну ефективність ринкової взаємодії для усіх заінтересованих сторін як системо-утворюючого компонента сфери продовольчого забезпечення. Осмислення проблеми обумовлює доцільність застосування стейкхолдерського підходу, практичний інструментарій якого, враховуючи вітчизняні особливості продовольчого забезпечення та вплив заінтересованих сторін, дозволить виявити причини дисбалансу їх економічних інтересів, що знаходять відповідне відображення в економічних ефектах від їх ринкової взаємодії.

У науковій літературі зустрічаються поодинокі праці, де робляться спроби застосовувати стейкхолдерський підхід для дослідження поведінкових стратегій суб'єктів ринку, керованих їх інтересами та очікуваннями на мезо- та макрорівні, проте стосовно контрагентів сфери продовольчого забезпечення подібні публікації відсутні. Також існує проблема частого ототожнення понять «продовольче забезпечення» та «продовольча безпека», хоча насправді друга із категорій є результатом, а перша - процесом, спрямованим на досягнення цього результату.

3 огляду на вищесказане, метою даного наукового дослідження є чітке розмежування дефініцій «продовольче забезпечення» $\mathrm{i}$ «про- 
довольча безпека» та доведення їх причинно-наслідкового зв'язку, а також визначення сутності категорії «сфера продовольчого забезпечення» в якості теоретичної основи для обгрунтування доцільності застосування стейкхолдерського підходу, орієнтованого на збалансування економічних інтересів заінтересованих сторін сфери продовольчого забезпечення з метою оптимізації економічних ефектів від їх ринкової взаємодії.

\section{2. Сфера продовольчого забезпечення як середовище взаємодії заінтересованих сторін}

Станом на теперішній час у світлі глобальних викликів та інтеграції вітчизняної економіки у світове господарство сформувалися нові тенденції, які є джерелами значних загроз для національної безпеки України, зокрема в частині збереження продовольчої незалежності. Тому створення сприятливих умов для фізичної та економічної доступності продуктів харчування за раціональною кількістю та структурою для усіх верств населення $\epsilon$ важливою умовою на шляху до продовольчого благополуччя.

3 огляду на це, продовольче забезпечення - це економічний процес, що передбачає проведення сукупності заходів щодо досягнення стійкої тенденції зростання кількісних і якісних параметрів продовольчого споживання, усунення ризиків порушення постачання продовольства шляхом створення надійних умов для стабільності виробництва i постачання продуктів харчування для всіх верств населення як запоруки продовольчої безпеки держави. Отже, продовольча безпека - це стан системної стабільності, що характеризується відсутністю загрози щодо отримання та споживання населенням дієтично повноцінних продуктів харчування відповідно до фізіологічних норм. Тому можна стверджувати, що продовольче забезпечення це дія, спрямована на досягнення результату - продовольчої безпеки.

Постачання продуктів харчування на вітчизняний ринок продовольства здійснюється завдяки жвавій міжнародній торгівлі та вітчизняному АПК, існуюча сукупність заінтересованих та/або функціонально взаємопов'язаних й взаємодіючих між собою суб'єктів яких формують простір - сферу продовольчого забезпечення. Вона відіграє роль середовища взаємодії господарюючих суб'єктів сторін ринку тріади «виробник-споживач-держава», кожній з яких властиві відпо- 


\section{Hlubish Lesia}

відні функції. Звідси, під сферою продовольчого забезпечення слід розуміти існуючу сукупність заінтересованих та/або функціонально взаємопов'язаних та взаємодіючих між собою суб'єктів, мотивованих до взаємодії економічною вигодою, відповідно до їх функціональних особливостей. Тобто це своєрідна модель конкурентного економічного середовища, в якому рішення про обсяги і структуру виробництва та споживання продуктів харчування приймаються суб'єктами господарювання в організаційно-правових рамках, продиктованих державою, яка є виробником і постачальником державних послуг як «виробникам», так і «споживачам» в обмін на сплату ними податків, тобто виступає в якості третього партнера, який, адекватно реагуючи на кон'юнктуру продовольчого ринку, своїми організаційно-регулюючими впливами встановлює правильний, необхідний для належного функціонування ринкового середовища порядок взаємодії всіх учасників тристоронніх стосунків [1, с. 72].

\section{3. Стейкхолдерський підхід забезпечення продовольчої безпеки}

Оскільки в ході взаємодії суб'єкти господарювання сторін ринку відіграють певну роль, отже можуть здійснювати вплив на загальну ситуацію у сфері продовольчого забезпечення, це обумовлює необхідність застосування стейкхолдерського підходу в ході дослідження проблеми продовольчого забезпечення населення країни. Означений підхід є одним із теоретичних напрямів у менеджменті, який формує i пояснює стратегію розвитку підприємства чи якоїсь сфери діяльності 3 точки зору врахування інтересів заінтересованих сторін. Аргументами на користь його використання $є$ те, що хоча він і не дає ніякої додаткової інформації про сферу продовольчого забезпечення, а лише дозволяє систематизувати вже наявну, означений підхід передбачає конкретну інституціоналізацію відносин держави із власниками засобів виробництва (й між ними самими), а також зі сторонами, які, через необхідність задоволення потреби у продовольстві, заінтересовані в товарообміні та відповідним чином впливають на функціонування існуючого механізму [2, с. 45-46]. Тому сфера продовольчого забезпечення може бути змодельована із використанням стейкхолдерького підходу, де трьома сторонами ринку є «держава», «виробник» $\mathrm{i}$ «споживач», що взаємодіють у просторі й часі через суб'єктів, мотивованих економічною вигодою, і відповідно до їх функціональних особливостей за допомогою 


\section{Expediency of using the stakeholder's approach for achieving the system...}

економічних, політичних, нормативно-правових, організаційно-управлінських, кадрових, науково-технічних та інших заходів впливають на процес продовольчого забезпечення з метою реалізації власних інтересів (рис. 1). Саме тому господарюючі суб'єкти сфери продовольчого забезпечення $є$ iï заінтересованими сторонами (стейкхолдерами), які будучи задіяні у даній сфері впливають на неї, а вона одночасно здійснює свій вплив на них. Попри те, що всі категорії стейкхолдерів взаємопов'язані та взаємозалежні - головна складність, пов'язана із можливістю оптимізувати взаємодію у сфері продовольчого забезпечення, криється у ідентифікації заінтересованих сторін. Вважаємо, що стейкхолдерів слід ідентифікувати відповідно до ролі, яку вони відіграють у сфері продовольчого забезпечення. Згідно класифікації Іва Фассіна [3, с. 122], стейкхолдери, що наділені потужними інструментами тиску на загальний стан справ у середовищі взаємодії є стейквочерами, сторони, що витупають в ролі регуляторів є стейккіперами, всі інші - стейкхолдерами, тобто тими, хто володіє часткою ринку, і відносини між якими носять конкурентний характер. Більшість стейкхолдерів пов'язані із групами тиску (стейквочерами), пов'язаними 3 певними регуляторами (стейккіперами), які, у свою чергу, впливають на стейкхолдерів. Окрім того, прагнучи лобіювати власні економічні інтереси, задля посилення ступеня впливу заінтересовані сторони можуть об'єднуватись, формуючи, у такий спосіб, групи економічного впливу - стейкхолдери «зливаються» зі стейккіперами, формуючи, у такий спосіб, домінуючу групу інтересів. Стейквочери, «зливаючись» зі стейкхолдерами, формують залежну групу інтересів, а із стейккіперами - небезпечну [4].

На прикладі сфери продовольчого забезпечення в якості стейкхолдерів виступатимуть господарюючі суб'єкти вітчизняного АПК, а також постачальники імпортного продовольства. Роль стейккіперів виконуватимуть державні інституції на кшталт Міністерства аграрної політики та продовольства України, яке розробляє державні програми підтримки та розвитку вітчизняного АПК; Верховна рада України, яка ухвалює подібні програми та законодавчі акти, що становлять правову основу ведення господарської діяльності у цій сфері; ПАТ «Аграрний фонд», головною функцією якого є врегулювання цінових дисбалансів на ринках аграрної продукції. Стейквочерами сфери продовольчого забезпечення є споживачі, потреби у продовольстві яких конче мають 


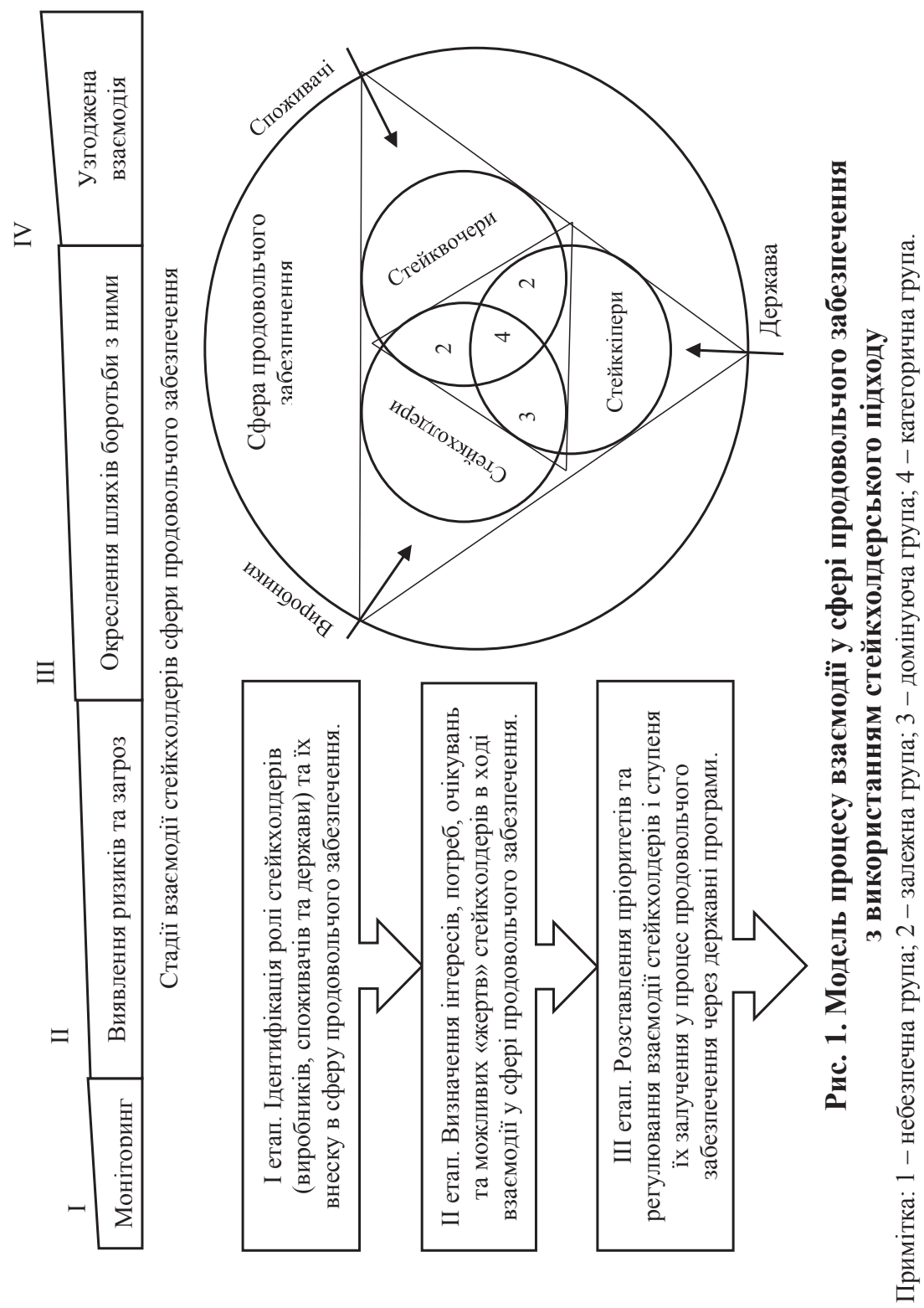




\section{Expediency of using the stakeholder's approach for achieving the system...}

бути задоволені. Незалежно від ролі, кожна із заінтересованих сторін може виступати як в якості потенційних бенефіціаріїв, так і можливих «жертв».

Попри бажання отримати гарантовану вигоду (виграш) усвідомлений частковий програш (втрата) кожної із заінтересованих сторін як своєрідна «жертва» здійснена на користь іншої є життєво необхідною для безперервного функціонування сфери продовольчого забезпечення як такої, оскільки забезпечуватиме відтворення економічних відносин, а отже гарантуватиме загальний виграш - продовольче благополуччя, що свідчитиме про частковий виграш кожної із сторін. Тому заінтересовані сторони сфери продовольчого забезпечення, частково узгоджуючи потреби, свідомо «ідуть» на частковий програш.

3 огляду на це, перефразовуючи Р. Коуза можна стверджувати, що мета продовольчої політики держави полягає у створенні такої ситуації, коли б люди, незалежно від власної ролі у сфері продовольчого забезпечення, приймаючи рішення про свою діяльність, вибирали такі 3 них, які забезпечують найкращі результати для системи загалом..., такі, що максимізують цінність усього іiї функціонування [5, с. 32].

\section{4. Ціннісна парадигма як компонента стейкхолдерського підходу}

Кожна із заінтересованих сторін $є$ виразником різних цінностей, які формують структуру і обсяги потреб та уособлюють особистісне цілісне сприйняття людиною корисності товару, тому у сучасних нестійких економічних умовах ціннісна парадигма виступає домінантою визначення цільових орієнтирів заінтересованих сторін, що $\epsilon$ регуляторами їх поведінки в ході ринкової взаємодії у сферах та галузях національної економіки.

Цінності суб'єктів ринкових відносин сфери продовольчого забезпечення - це ті чинники, що визначають цілі заінтересованих сторін та спонукають їх до певної економічної поведінки у середовищі взаємодії. Саму ж економічну поведінку заінтересованих сторін можна визначити як комбінування цілеспрямованих і спонтанних дій, а також реакцій, обумовлених впливом об'єктивних і суб'єктивних чинників, орієнтовану на досягнення пріоритетних цілей в умовах вибору та адаптації до змінних економічних умов.

Попри те, що деякі базові цінності локальних соціумів і суспільства загалом, з одного боку, і частина базових цінностей бізнесу, з другого - 


\section{Hlubish Lesia}

різняться [6, с. 62] видається цілком можливим гарантування оптимального забезпечення населення продовольством, шляхом ведення грамотної продовольчої політики, яка повинна мати системний характер та охоплювати не лише виробничу, а й споживчу сфери, враховуючи національні особливості, включати питання здорового харчування населення, якості та безпеки продовольства, розвитку сільських територій, наукового його забезпечення.

Стейкхолдерський підхід є досить зручним та достатньо ефективним інструментом, який дозволяє визначити місію, стратегічну мету i тактичну ціль функціонування сфери продовольчого забезпечення, а також ії суб’єктно-функціональних складових (рис. 2).

Перехід від одного політичного ладу до іншого завжди супроводжується боротьбою цінностей. Через розвал Радянського Союзу та відсутність чіткого вектора розвитку України впродовж усього періоду незалежності, для сучасного іiі населення характерна відсутність чіткої системи цінностей. Це спричинило появу певних диспропорцій і у економічній взаємодії, а саме у поведінкових стратегіях господарюючих суб'єктів, що призвело до дисбалансу обсягів виробництва через негативні тенденції у культурі споживання. Не зважаючи на те, що попит на продовольчі товари є постійним, викликає занепокоєння рівень достатності споживання основних продуктів харчування - він свідчить про розбалансованість харчових раціонів населення України.

3 огляду на це, актуалізується питання гармонізації відносин у сфері продовольчого забезпечення. Серед чинників, що спричинили різну динаміку розвитку іiі суб'єктно-функціональних складових важливе значення має різновекторність їх цілеспрямованості. Вважаємо, що формулюючи мету та цілі господарської діяльності, кожен суб'єкт ринкових відносин має орієнтуватися на загальну місію функціонування сфери продовольчого забезпечення - здоров'я нації. Адже, не має значення в якій ролі людина задіяна у процесі продовольчого забезпечення, потреба у продуктах харчування $є$ однією із фізіологічних потреб кожного. Натомість неабияке значення має стан здоров'я, від якого залежить рівень продуктивності праці людини ії інтелектуальний та трудовий потенціал, а отже і розвиток окремих структурно-функціональних складових, сфер, галузей та, зрештою, економіки загалом. 




\section{Рис. 2. Дерево цілей функціонування сфери продовольчого забезпечення}

\section{5. Баланс інтересів стейкхолдерів як передумова ефективного функціонування сфери продовольчого забезпечення}

В сукупності цінності та цілі заінтересованих сторін $є$ базисом для формування економічних інтересів, які відіграють важливу роль у стратегії і тактиці політики продовольчої безпеки. Реалізуючи на 


\section{Hlubish Lesia}

практиці своє цільове призначення, кожен із учасників ринкових відносин сфери продовольчого забезпечення, керований усвідомленою вигодою, відповідно до поставленої мети, переслідує власні інтереси і реалізує їх, виконуючи властиві йому функції в ході конкурентних економічних відносин. Звідси, під економічним інтересом слід розуміти усвідомлену заінтересованою стороною економічну вигоду, очікувану від реалізації стратегії взаємодії. Зміст та форма самої ринкової взаємодії визначається множиною факторів впливу і підпорядковується об'єктивним економічним законам та закономірностям, що породжуються існуючими виробничо-господарськими відносинами.

Для кожної заінтересованої сторони властивий власний економічний інтерес, який є причиною виникнення цілеспрямованих та скоординованих соціальних дій i/або господарської діяльності задля отримання вигоди або ж досягнення очікуваної зміни. Досліджуючи економічні інтереси з позицій системного підходу, в якості «входу» в систему реалізації економічних інтересів у процесі продовольчого забезпечення необхідно розглядати внутрішню сутність потреб, усвідомлення якої дозволяє трансформувати їх у інтереси заінтересованих сторін. Тоді як «виходом» 3 даної системи слід вважати, одержані в результаті ринкової взаємодії, реалізовані на практиці цілі економічних суб'єктів - носіїв економічних інтересів. Це свідчить про взаємозалежність заінтересованих сторін, яка обумовлює їх співробітництво, бо не задовольнивши економічні інтереси одна одної, жодна сторона ринкової взаємодії не зможе реалізувати власних. Звідси, система реалізації економічних інтересів уособлює єдність взаємопов'язаних i взаємодіючих між собою структурних елементів сфер та галузей, економічні інтереси яких виникають і реалізуються в ході їх ринкової взаємодії, обумовленої відносинами власності, принципом економічної вигоди, мотивами і стимулами, через досягнення ними конкретних економічних цілей, що виражають міру задоволення їх економічних потреб, спектр яких формується під впливом системи цінностей навіяних нагальними проблемами часу, та еволюціонує відповідно до етапів розвитку економічних відносин.

Таким чином, економічні інтереси заінтересованих сторін сфери продовольчого забезпечення слугують пусковим механізмом ринкових відносин щодо задоволення економічних потреб, через споживання економічних благ, в ході взаємодії в ринковому середовищі, де 
вони реалізуються внаслідок певної діяльності задля досягнення очікуваного економічного ефекту. Тоді як оцінка одержаних економічних ефектів закладає основу для формування економічних інтересів. Обгрунтовуючи такий підхід, слід попередити хибне уявлення про статичність процесу формування, трансформації та реалізації економічних інтересів, що свідчить про циклічний характер процесу реалізації економічного інтересу (рис. 3).

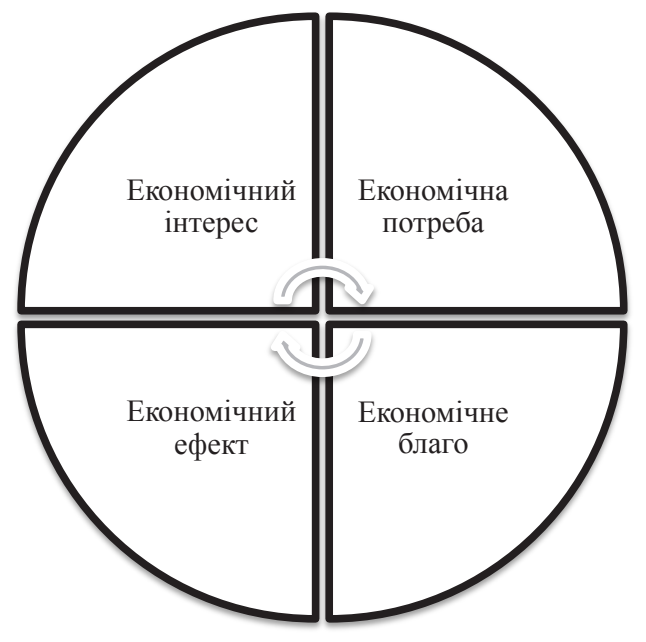

\section{Рис. 3. Циклічність процесу реалізації економічного інтересу}

Беручи до уваги той факт, що вони є суспільною формою прояву, усвідомленим прагненням суб'єктів ринкової взаємодії до задоволення економічних потреб, а також зважаючи на різноманітність чинників, під впливом яких вони розвиваються, цей процес слід вважати явищем динамічним.

Множинність функціонально-суб'єктних складових сфери продовольчого забезпечення і різноспрямованість їх економічних інтересів породжують низку протиріч. Адже держава, виробник та споживач $\epsilon$ протилежними сторонами ринкових відносин, заінтересовані сторони яких переслідують протилежні цілі, тому їх економічні інтереси мають суперечливий характер. Водночас спільним прагненням для усіх $є$ максимізація вигоди за умови мінімізації витрат. 


\section{Hlubish Lesia}

Зокрема, споживач прагне задовольнити свої потреби в продовольстві, отримавши максимум користі від спожитих товарів, заплативши за них низьку ціну. Виробник, навпаки, переслідує ціль реалізувати продовольчу продукцію за максимально високою ціною, мінімізувавши витрати на їі виробництво. Економічні інтереси кожної із заінтересованих сторін мають право бути реалізованими, проте до певної граничної межі - допоки вони не перешкоджають реалізації економічних інтересів інших заінтересованих сторін середовища взаємодії, створюючи загрозу стійкому стану системної стабільності процесу продовольчого забезпечення. Сама ж стійкість забезпечується компромісом заінтересованих сторін щодо збалансування їх економічних інтересів 3 метою недопущення їх опортуністичної поведінки у процесі досягнення поставлених ними цілей. Тобто слід досягти такої структурної пропорції в розподілі економічної вигоди між заінтересованими сторонами, яка б забезпечувала не лише стійкість, але й синергізм господарсько-економічних зав'язків. Цьому процесу передує встановлення співвідношення між чинниками, що сприяють та стримують процес досягнення стану системної стабільності продовольчого забезпечення населення України (рис. 4). Аналіз поля сил дозволяє окреслити чіткі загрози та, відповідно до них, вибудувати систему пріоритетів стратегічного розвитку сфери продовольчого забезпечення на конкретну перспективу, враховуючи отриманий досвід та національні особливості іiі становлення і функціонування.

Усунути виявлені в ході аналізу поля сил стану системної стабільності процесу продовольчого забезпечення слабкі сторони та потенційні загрози повинна саме держава, врівноважуючи, діалектичний взаємозв'язок економічних інтересів виробників і споживачів на принципах часткового узгодження економічних потреб та відповідного їх задоволення. Із частковим узгодженням економічних потреб виробника і споживача та відповідним їх задоволенням ототожнюється рівність граничних жертв, яка є головною умовою узгодженої ринкової взаємодії, бо саме вона $є$ тим інструментом, що дозволяє досягти бажаного результату функціонування сфери продовольчого забезпечення, а не максимально можливої економічної вигоди.

Аналіз поля сил дає підстави для такого загального висновку Україна має необхідний потенціал для досягнення стану системної стабільності процесу продовольчого забезпечення, а наявність загроз 


\section{Expediency of using the stakeholder's approach for achieving the system...}

Досягнення стійкого стану системної стабільності, що характеризується відсутністю загрози щодо виробництва, надходження та споживання населенням дієтично повноцінних продуктів харчування відповідно до фізіологічних норм

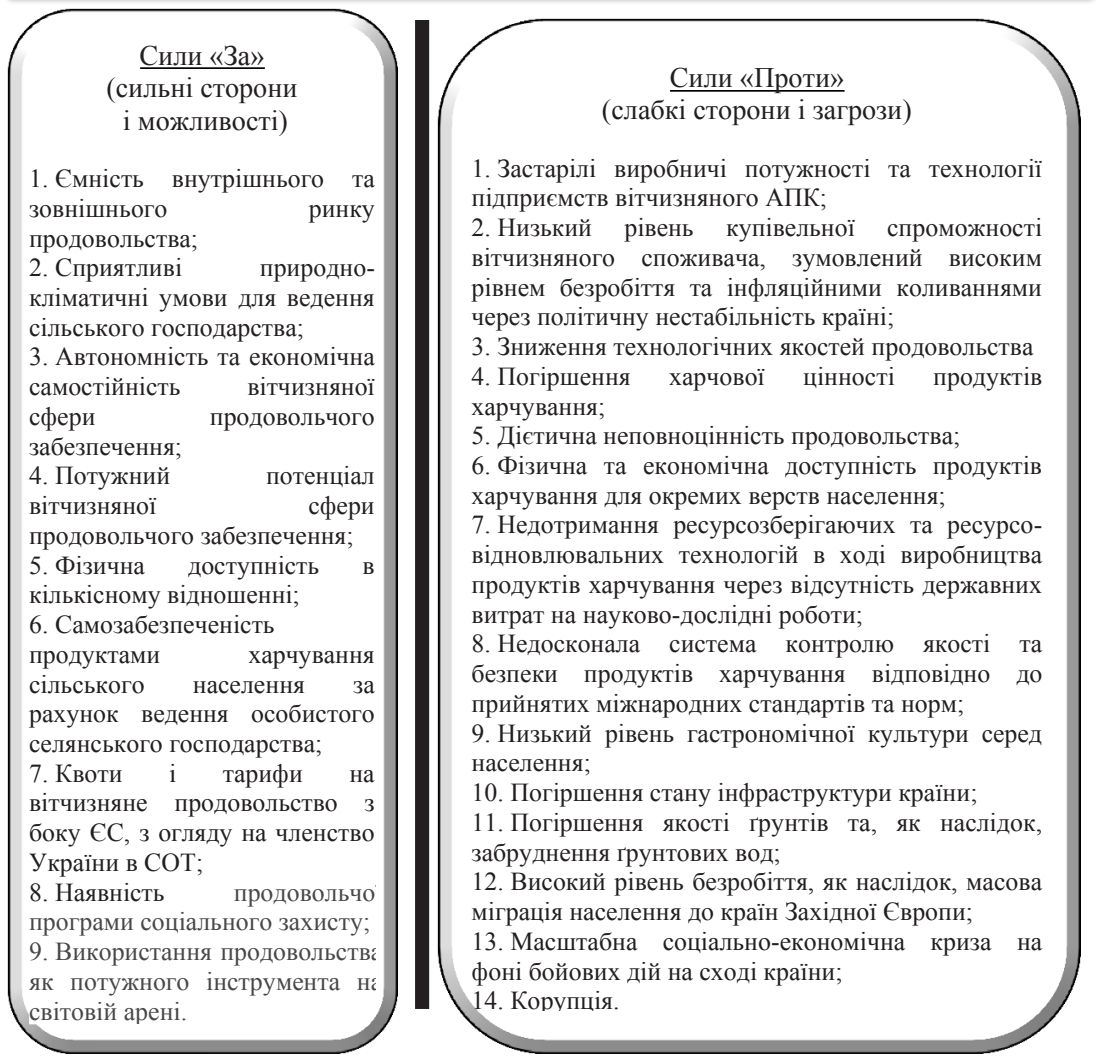

\section{Рис. 4. Аналіз поля сил досягнення стану системної стабільності процесу продовольчого забезпечення}

щодо нього зумовлена відстороненням держави від регуляторних процесів.

Головними напрямами державного втручання має стати здійснення заходів щодо матеріально-технічного та техніко-технологічного оновлення стейкхолдерів вітчизняного АПК, відновлення та розвитку інфраструктури, жорсткого контролю за відповідністю продуктів хар- 


\section{Hlubish Lesia}

чування на вітчизняному ринку продовольства міжнародним нормам і стандартам, а також пропагування гастрономічної культури споживання продуктів харчування населенням. Взаємно-узгоджена реалізація економічних інтересів потребує активізації діяльності держави, яка, вміло використовуючи наявні регуляторні важелі, включаючи правову базу, покликана створити і підтримувати такі умови, які б сприяли ефективній взаємодії та реалізації економічних інтересів всіх іiі учасників. Для гармонізації економічних відносин, зважаючи на обмеженість фінансових ресурсів, держава 3 огляду на чіткі національні пріоритети визначає параметри поведінки ринкових суб'єктів, вводячи певні правові та економічні обмеження, прагне досягти оптимально ефективних результатів функціонування. Вирішення проблем конфронтації та різновекторності прагнень щодо отримання економічної вигоди між сторонами ринкової взаємодії можливе через узгодження економічних інтересів на основі принципу рівності граничних жертв. Він $є$ ключем ефективного функціонування кожної з трьох сторін ринкової взаємодії (споживача, виробника, держави), тоді як слабкість стану будь-якої 3 них зводить до мінімуму ефективність інших та ефективність економічної системи загалом.

\section{6. Ефект взаємодії заінтересованих сторін сфери продовольчого забезпечення}

Економічні інтереси стейкхолдерів, уособлюючи усвідомлену вигоду, реалізуються через досягнення конкретних економічних ефектів, які виражають міру задоволення економічних потреб, спектр яких формується під впливом системи цінностей. Таким чином, цілі та сформовані під їх впливом інтереси мотивують ринкові відносини щодо задоволення економічних потреб через споживання економічних благ, об'єктом яких є найбільш бажаний результат (ефект) з їх множини (рис. 5).

Економічні ефекти оцінюються з різних позицій із використанням відповідного інструментарію. Під ефектом прийнято розуміти результат [7, с. 60-61], наслідок [8, с. 103], зміну стану певного суб'єкта [9, с. 151-152], зумовлену дією зовнішніх або внутрішніх чинників, а також факторів, або їх сукупності.

Відповідно, ефект може бути як позитивним, коли його зміни $\epsilon$ корисними, так і негативним, коли зміни деструктивні, або ж нульо- 


\section{Expediency of using the stakeholder's approach for achieving the system...}

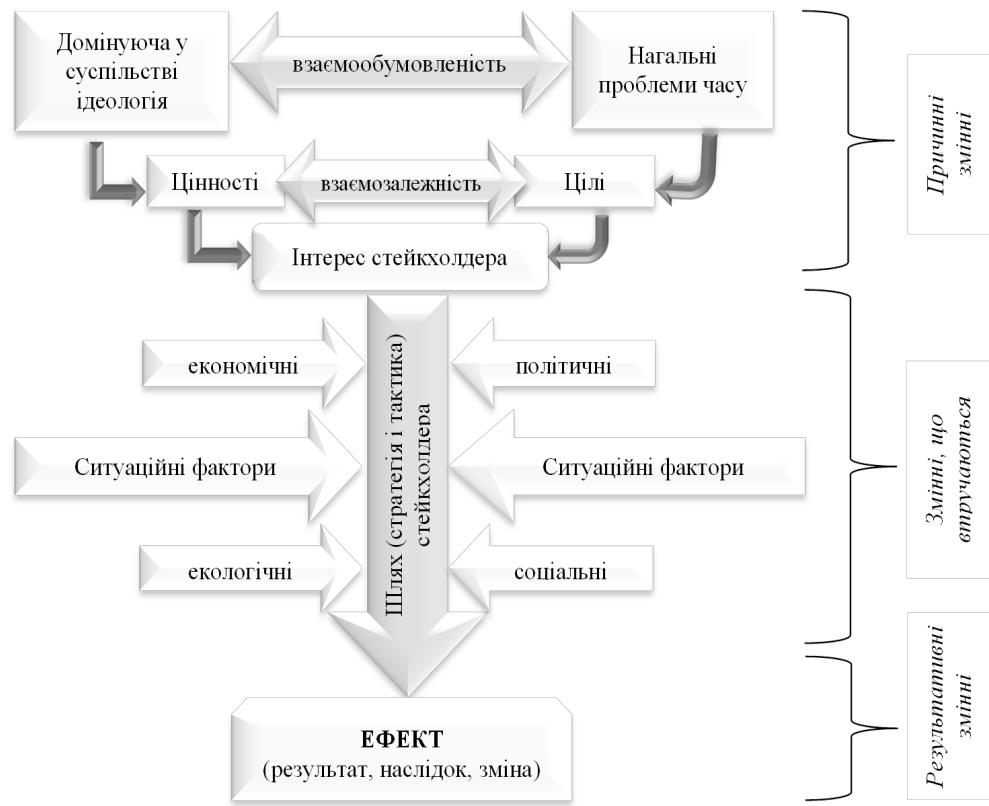

\section{Рис. 5. Формування ефектів поведінкових стратегій заінтересованих сторін}

вим, коли зміни відсутні взагалі [10, с. 134]. Звідси, ефекти різної природи можуть підсилювати або послаблювати однин одного, або бути нейтральними $[11$, с. 70], що в ході ринкової взаємодії стейкхолдерів визначає їх ділову активність, що базується на порівнянні можливих переваг, котрі зможе отримати носій економічного інтересу за умови дотримання ним чіткої послідовності дій (стратегії поведінки).

Головним ефектом взаємодії заінтересованих сторін сфери продовольчого забезпечення є досягнення стану системної стабільності процесу продовольчого забезпечення населення країни, який має гарантувати продовольчу безпеку. Агрегованим показником, що відображає рівень продовольчої безпеки в країні $є$ Глобальний індекс продовольчої безпеки (The Global Food Security Index 2017) [12], який визначається за підтримки американської транснаціональної компанії DuPont Інститутом економічних досліджень (The Economist Intelligence Unit), пропонує 28 унікальних індикаторів, класифікованих за трьома групами: 


\section{Hlubish Lesia}

доступність (питома вага витрат домашніх господарств на харчування в загальному їх обсязі, валовий внутрішній продукт на душу населення та ін.); наявність (достатність харчування, державні витрати на сільськогосподарські НДР, стан сільськогосподарської інфраструктури, політична стабільність, корупція та ін.); якість і безпека (різноманітність харчування та його норми, доступність мікроелементів, якість білка, безпека харчових продуктів та ін.) (табл. 1). Схема визначення індексу базується на положеннях міжнародно визнаного у 1996 році Всесвітнього продовольчого саміту [13].

Таблиця 1

Динаміка стану продовольчої безпеки України

\begin{tabular}{|c|c|c|c|c|c|c|c|c|c|c|c|c|}
\hline \multirow[b]{2}{*}{ Показник } & \multicolumn{6}{|c|}{$\begin{array}{c}\text { Оцінка } \\
\text { (за 100-бальною шкалою) }\end{array}$} & \multicolumn{6}{|c|}{$\begin{array}{l}\text { Місце у рейтингу } \\
\text { (серед } 109 \text { країн) }\end{array}$} \\
\hline & $\frac{\dot{\lambda}}{\stackrel{\sim}{\tilde{~}}}$ & $\stackrel{\dot{m}}{\stackrel{\sim}{\tilde{N}}}$ & $\stackrel{\dot{\sim}}{\dot{\sim}}$ & $\stackrel{\dot{2}}{\stackrel{n}{\bar{\pi}}}$ & 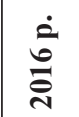 & 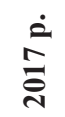 &  & 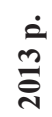 & $\stackrel{\dot{\Delta}}{\stackrel{\dot{d}}{\vec{N}}}$ & $\frac{\dot{a}}{\stackrel{n}{\tilde{N}}}$ & $\stackrel{\dot{a}}{\stackrel{2}{0}}$ & $\frac{\dot{2}}{\stackrel{\sim}{*}}$ \\
\hline Загал & 56,7 & 57,5 & 57,7 & 56,1 & 56,4 & 54,1 & 52 & 51 & 53 & 59 & 52 & 63 \\
\hline Доступність & 55,6 & 55,6 & 58,7 & 58,6 & 50,4 & 55,7 & 53 & 53 & 50 & 54 & 50 & 59 \\
\hline Наявність & 54,2 & 56,3 & 53,6 & 58,6 & 79,9 & 50,2 & 55 & 54 & 59 & 71 & 64 & 78 \\
\hline Якість і безпека & 66,1 & 65,7 & 66,7 & 62,6 & 60,0 & 61,0 & 40 & 44 & 41 & 48 & 42 & 51 \\
\hline
\end{tabular}

До числа проблем, існуючих у вітчизняній сфері продовольчого забезпечення належать: самозабезпеченість продуктами харчування населенням країни (у великих містах (понад 100 тис. жителів) його частка становить близько 2 \%, що наближається до рівня цього показника в розвинутих країнах, у малих містах натуральний сегмент продовольчого ринку сягає вже $12 \%$ його загального обсягу, а в сільській місцевості - перевищує 46 \%); недостатність попиту, зумовлена змінами у статевовіковій структурі населення та падінням його купівельної спроможності через випереджаючі темпи зростання рівня цін на комунальні послуги та інші блага (в т. ч. і на продовольство) порівняно із темпами росту заробітної плати, пенсій, стипендій; скорочення пропозиції продовольства, високий рівень безробіття і низькі темпи економічного зростання у сфері продовольчого забезпечення.

Необхідність своєчасної сплати комунальних платежів а також суттєве подорожчання транспортних послуг змушує пересічного українця 
надавати перевагу відносно дешевим вуглеводовмісним та протеїновмісним продуктам харчування. Нестача у харчових раціонах українців усіх основних харчових продуктів багатих на вітаміни, мікроелементи та білки тваринного походження $є$ причиною погіршення їх здоров'я, працездатності і демографічного відтворення населення. Саме тому пропонується доповнити перелік індикаторів доцільно розширити Глобальний індекс продовольчої безпеки показниками середнього споживання населенням вуглеводів, жирів та білків, вітамінів, а також мікроелементів та жирних кислот, характеристичні значення яких доречно узгодити з рекомендаціями Всесвітньої організації охорони здоров'я [14, с. 17]. Задля усунення існуючих проблем у вітчизняній сфері продовольчого забезпечення, державі одночасно із підвищенням вартості робочої сили та регулюванням цін, слід подбати про зростання доходів громадян шляхом підвищення зайнятості населення, а також скорочення сукупних витрат, використовуючи нестандартні підходи - пропагуючи здоровий спосіб життя, дбаючи про енергетичну безпеку, використовуючи альтернативні джерела енергії, розвиваючи власні нафтогазові родовища.

Отже, проблему продовольчого забезпечення не слід вирішувати відособлено, а навпаки, враховуючи циклічність функціонування економічних систем, явищ і процесів, підпорядкованих дії закону єдності й боротьби протилежностей. Зокрема, для вітчизняної сфери продовольчого забезпечення можна окреслити такі три рівня створення загальних цінностей: вирішити питання харчової цінності харчового раціону, зниження вартості базових продуктів харчування; покращити доступ дрібних товаровиробників до інформації та технічної підтримки для створення більш надійної і високоякісної мережі постачальників продовольства до ринків збуту; забезпечити підтримку розвитку інфраструктури, доступ до фінансових ресурсів.

\section{7. Висновки}

За результатами проведеного дослідження встановлено, що продовольче забезпечення це дія, спрямована на досягнення результату - продовольчої безпеки та визначено сутність поняття сфери продовольчого забезпечення в якості середовища взаємодії заінтересованих сторін. Обгрунтовано доцільність застосування стейкхолдерського підходу як зручного та ефективного інструмента забезпечення продовольчої без- 


\section{Hlubish Lesia}

пеки, який дозволяє визначити місію, стратегічну мету і тактичну ціль функціонування сфери продовольчого забезпечення, а також iіi суб'єктно-функціональних складових. 3'ясовано, що ціннісна парадигма виступає домінантою визначення цільових орієнтирів заінтересованих сторін, що є регуляторами їх поведінки в ході ринкової взаємодії, тоді як цінності та цілі формують інтереси заінтересованих сторін. Для гармонізації економічних відносин та вирішення проблем конфронтації та різновекторності прагнень щодо отримання економічної вигоди між сторонами ринкової взаємодії необхідним є збалансування інтересів заінтересованих сторін на основі результатів аналізу поля сил досягнення стану системної стабільності процесу продовольчого забезпечення, який дозволяє окреслити чіткі загрози та, відповідно до них, вибудувати систему пріоритетів стратегічного розвитку сфери продовольчого забезпечення на конкретну перспективу, враховуючи отриманий досвід та національні особливості ії становлення і функціонування.

Таким чином, сфера продовольчого забезпечення може бути змодельована із використанням стейкхолдерського підходу орієнтованого на збалансування економічних інтересів заінтересованих сторін сфери продовольчого забезпечення з метою оптимізації економічних ефектів від їх ринкової взаємодії.

Перспективи подальших наукових досліджень у цьому напрямку полягають у побудові оптимізаційних моделей функціонування сфери продовольчого забезпечення.

\section{Список літератури:}

1. Петренко В. П. До визначення шляхів оптимізації стосунків держави, виробників і споживачів 3 використанням закономірностей парето-ефективного ринку / В. П. Петренко // Науковий вісник ІФНТУНГ. - 2002. № 4. - С. 71-76.

2. Кушнір Л. Л. Проблема ідентифікації стейкхолдерів у системі ресурсного забезпечення національної економіки / Л. Л. Кушнір // Науковий вісник Полтавського університету економіки і торгівлі. - № 6 (51), Ч. 1. 2011. - C. 43-49.

3. Fassin, Y. (2005), "The Reasons Behind Non-Ethical Behavior in Business and Entrepreneurship", Journal of Business Ethics, Vol. 60, P. 122.

4. Глубіш Л. Я. Взаємозалежність та взаємообумовленість ціннісного та цілісного підходів щодо формування економічних ефектів від взаємодії стейкхолдерів сфери продовольчого забезпечення : [Електронний pecypc] / Л. Я. Глубіш // Ефективна економіка. - Режим доступу: http://www.m.nayka.com.ua/?op=1\&j=efektyvna-ekonomika\&s=ua\&z=5642. 


\section{Expediency of using the stakeholder's approach for achieving the system...}

5. Coase R. The Firm, the Market and the Law. Chicago \& London, The University of Chicago Press, 1988. 226 p. (Russ. ed.: Kouz R. Firma, rynok, pravo. Moscow, Novoe izdatelstvo Publ., 2007. 224 p.).

6. Попов С. А. К созданию общих ценностей... от теории стейкхолдеров к реализации концепции общих ценностей / С. А. Попов, Л. Л. Фомина // Российское предпринимательство. - 2013. - № 2 (224). - С. 60-65.

7. Кісіль М. І. Критерій і показники економічної ефективності малого та середнього бізнесу на селі / М. І. Кісіль // Економіка АПК, 2001. № 8. - С. 59-64.

8. Економіка сільського господарства. / П. П. Руснак, В. В. Жебка, М. М. Рудий, А. А Чалий. - К. : Урожай, 1998. - 320 с.

9. Хашковская О. А. Оценка экономической эффективности функционирования сельскохозяйственных предприятий в условиях социальной переориентации народнохозяйственных комплексов Беларуси / О. А. Хашковская // Економіка АПК. - 2004. - № 11. - С. 149-153.

10. Перекрест Т. В. Методологія оцінювання ефективності діяльності підприємства / Т. В. Перекрест // Держава та регіони. Серія: економіка і підприємництво. - 2011. - № 4. - С. 130-136.

11. Прядко В. В. Теоретико-методологічні аспекти ефективності сільськогосподарського виробництва / В. В. Прядко / Економіка АПК. - 2003. № 10 . - C. 69-77.

12. The Global Food Security Index 2017. [Electronic resource]. - Access mode : http://foodsecurityindex.eiu.com/Index.

13. FAO 1996. Rome Declaration of World Food Security and World Food Summit Plan of Action. [Electronic resource]. - Access mode :http:/www.fao.org

14. Полторак А. С. Комплексна оцінка стану продовольчої безпеки України / А. С. Полторак // Economic Annals-XXI (2015), 7-8(2), p. 15-18.

\section{References:}

1. Petrenko V. P. (2002). Do vyznachennya shlyakhiv optymizatsiyi stosunkiv derzhavy, vyrobnykiv i spozhyvachiv z vykorystannyam zakonomirnostey paretoefektyvnoho rynku [For identify ways of optimizing relationships, manufacturers, consumers and government using regularities Pareto efficient market]. Naukoviy visnyk IFNTUNH, no 4, pp. 71-76 (In Ukr.).

2. Kushnir L. L. (2011). Problema identyfikatsiyi steykkholderiv u systemi resursnoho zabezpechennya natsional'noyi ekonomiky [The problem identification of stakeholders in the resource system of the national economy]. Naukovyy visnyk Poltavs'koho universytetu ekonomiky i torhivli. vol. 1, no 6 (51), pp. 43-49.

3. Fassin, Y. (2005). The Reasons Behind Non-Ethical Behavior in Business and Entrepreneurship. Journal of Business Ethics, vol. 60, P. 122.

4. Hlubish L. Ya. (2017). Vzayemozalezhnist' ta vzayemoobumovlenist' tsinnisnoho ta tsilisnoho pidkhodiv shchodo formuvannya ekonomichnykh efektiv vid vzayemodiyi steykkholderiv sfery prodovol'choho zabezpechennya [The interdependence and interconditionality of worth and aim approaches about of forming economic effects of the stakeholders interaction of provision supply sphere]. Efektyvna ekonomika (electronic journal), no. 6. Retrieved from: 


\section{Hlubish Lesia}

http://www.m.nayka.com.ua/?op=1\&j=efektyvna-ekonomika\&s $=u a \& z=5642$ (accessed 11 june 2017).

5. Coase R. (1988). The Firm, the Market and the Law. Chicago \& London, The University of Chicago Press. 226 p.

6. Popov S. A. \& Fomina L. L. (2013). K sozdanyyu obshchykh tsennostey... ot teoryy steykkholderov k realyzatsyy kontseptsyy obshchykh tsennostey. [To the creation of common values ... from the theory of stakeholders to the realization of the concept of common values]. Rossyyskoe predprynymatel'stvo, no 2 (224), pp. 60-65.

7. Kisil M. I. (2001). Kryteriy i pokaznyky ekonomichnoyi efektyvnosti maloho ta seredn'oho biznesu na seli [Criteria and indicators of economic efficiency of small and medium enterprises in rural areas]. Ekonomika APK, vol. 8, pp. 59-64.

8. Rusnak P. P., Zhebka V. V., Rudyi M. M. \& Chalyi A. A. (1998). Ekonomika silskoho hospodarstva [Agrarian economy]. Kyiv: Urozhai. (in Ukrainian)

9. Khashkovskaia O. A. (2004). Otsenka эkonomycheskoy эffektyvnosty funktsyonyrovanyya sel'skokhozyaystvennukh predpryyatyy v uslovyyakh sotsyal'noy pereoryentatsyy narodnokhozyaystvennыkh kompleksov Belarusy [Estimation of economic efficiency of functioning of agricultural enterprises in conditions of social reorientation of national economic complexes of Belarus]. Ekonomika APK, no. 11, pp. 149-153.

10. Perekrest T. V. (2011). Metodolohiya otsinyuvannya efektyvnosti diyal'nosti pidpryyemstva [Methodology for evaluating the effectiveness of the company]. Derzhava ta rehiony. Seriia: ekonomika i pidpryiemnytstvo, no. 4, pp. 130-136.

11. Priadko V. V. (2003). Teoretyko-metodolohichni aspekty efektyvnosti sil's'kohospodars'koho vyrobnytstva [Theoretical aspects of agricultural production efficiency], Ekonomika APK, no. 10, pp. 69-77.

12. The Global Food Security Index 2017. [Electronic resource]. - Retrieved from : http://foodsecurityindex.eiu.com/Index.

13. FAO 1996. Rome Declaration of World Food Security and World Food Summit Plan of Action. [Electronic resource]. - Retrieved from: http://www.fao.org

14. Poltorak A. S. (2015). Kompleksna otsinka stanu prodovol'choyi bezpeky Ukrayiny [Harmonization of Ukraine's legislation covering the assessment of food security with international standards]. Economic Annals-XXI, no 7-8(2), pp. 15-18. 